УДК 159.937.22-057.874

DOI https://doi.org/10.32838/2709-3093/2021.3/24

Фоміна I.C.

Херсонський державний університет

Лось O.M.

Херсонський державний університет

\title{
ПСИХОЛОГО-ПЕДАГОГІЧНИЙ СУПРОВІД РОЗВИТКУ ЕМПАТІЇ В МОЛОДШИХ ШКОЛЯРІВ
}

У статті розглянуто супровід як основу професійної діяльності шкільних психологів, який орієнтований на створення умов розвитку емпатї кожної дитини в ситуаціях шкільної взаємодіï.

Для здійснення психолого-педагогічного супроводу розвитку емпатії в молодших школярів психологи пропонують використовувати різноманітні види діяльності: ігри, продуктивні види діяльності, предметну діяльність, спостереження, спілкування. Спеціальні методики на заняттях із дітьми дозволяють фіксувати процес розвитку рівня емпатії, моральних знань дітей, досвіду поведінки, і ступінь просування або зміни в иіннісних орієнтаціях особистості.

Одним з основних завдань психолого-педагогічного супроводу розвитку емпатії в молодших школярів є розвиток здатності дітей до диферениіації емочійних станів через усвідомлення власних переживань. Із иією метою використовуються елементи психогімнастики (за методикою Г. Бардієр, І. Ромазан, Т. Чередникової). Успішний психолого-педагогічний супровід розвитку емпатї̈ й емпатійної поведінки в молодших школярів можливий на базі розвитку творчої уяви за умови поєднання видів дитячої діяльності.

Тематичний урок як елемент виховного процесу виконує навчальну, виховну та розвивавальну функиії, він дозволяє сформувати у школярів більш повні уявлення про гуманні якості особистості, ї̈ ставлення до них, а також сприяє формуванню в дітей потреби в гуманній поведіниі.

У процес психолого-педагогічного супроводу розвитку емпатії природно включені методичні прийоми, які дозволяють психологу вивчати особливості дітей, простежувати динаміку їхнього розвитку, а також коректувати поведінку молодших школярів, ӥхні взаємини в колективі.

Ключові слова: емпатія, розвиток особистості, молодші иколярі.

Постановка проблеми. Концепція супроводу як напряму в наданні допомоги дітям почала розроблятися в нашій країні із середини 90-х рр. минулого століття. В ï основі лежить досвід роботи психолого-медико-педагогічних комісій та спеціалізованих установ у системі освіти.

Психолого-педагогічний супровід - діяльність психологів та педагогів із надання превентивної, оперативної допомоги дітям у вирішенні їхніх індивідуальних проблем, пов'язаних із фізичним та психологічним здоров'ям, спілкуванням, успішним просуванням у навчанні, життєвим i професійним самовизначенням [3, с. 37].

Супровід як основа професійної діяльності шкільних психологів орієнтований на створення умов розвитку кожної дитини в ситуаціях шкільної взаємодії. Завданням такого супроводу є розроблення та впровадження у шкільну практику таких умов і ситуацій, які забезпечу- вали б кожній дитині можливість задовольняти свої потреби.

Аналіз останніх досліджень і публікацій. Широкий інтерес до проблеми емпатії, зокрема й емпатії молодших школярів, не згасає протягом багатьох десятиліть, що говорить про величезну важливість цього процесу в розвитку особистості та моральних почуттів людини. Розвиток емпатії особливо важливий у період молодшого шкільного віку, коли в дітей інтенсивно починають розвиватися моральні цінності, нові погляди на відносини між людьми.

Незважаючи на те, що у психології є багато досліджень, присвячених феномену емпатії, таких авторів, як А. Сміт, Г. Спенсер, А. Шопенгауер, М. Шелер, однозначної думки про структуру та сутність даного явища натепер немає [6]. Сучасними дослідниками емпатія розглядається i як емоційне явище, і як процес розуміння іншої людини, iї думок та переживань. 
Постановка завдання. Мета статті - розглянути супровід як основу професійної діяльності шкільних психологів, який орієнтований на створення умов розвитку емпатії кожної дитини в ситуаціях шкільної взаємодії.

Виклад основного матеріалу дослідження. Для здійснення психолого-педагогічного супроводу розвитку емпатії в молодших школярів психологи пропонують використовувати різноманітні види діяльності: ігри, продуктивні види діяльності, предметну діяльність, спостереження, спілкування (як самостійно, так і в комплексі). Підходи до відбору змісту на всіх етапах діяльності розглядаються комплексно, у контексті гуманного ставлення дитини до людей та навколишнього світу. На основі сучасної класифікації методів виховання (I. Подласов), можна виділити три групи методів розвитку емпатії молодших школярів у психолого-педагогічному супроводі. По-перше, це методи формування знань про моральні цінності, які забезпечують знайомство молодших школярів із моральними нормами та правилами поведінки. До них належать такі: роз'яснення, навіювання, звернення до почуттів, обговорення, читання оповідань та казок, етична бесіда.

По-друге, методи організації діяльності та розвитку емпатії засновані на практичній діяльності молодших школярів та включають вправи, вимоги, доручення, колективні ігри, аналіз виховної ситуації, імпровізацію, рефлексію.

По-третє, для підкріплення сформованих якостей молодшому школяреві необхідні методи стимулювання: заохочення, осуд, змагання, стимулювання інтересу.

Основними умовами психолого-педагогічного супроводу розвитку емпатії в молодших школярів $€$ :

- групова форма роботи;

- проведення корекційних занять в емоційно насиченій обстановці;

- систематичність роботи 3 молодшими школярами;

- активна робота дітей на коректувальному занятті.

Як зазначають деякі автори (Г. Бардіер, I. Ромазан, Т. Чередникова), можна виділити такі умови для психолого-педагогічного супроводу розвитку емпатії в молодших школярів:

- складання програми психолого-педагогічного супроводу так, щоб за збереження мети того чи іншого заняття можна було варіювати всім іншим матеріалом, завданнями, інструкціями, часом, місцем проведення занять;
- супроводжування дитини до самостійності, намагаючись не управляти нею, не зобов'язувати ii, не обмежувати фантазію, не пригнічувати $[2$, c. 3$]$.

Також варто виділити такі напрями психологопедагогічного супроводу, як:

- діагностика розвитку дитини;

- актуальний напрям, орієнтований на подолання вже наявних труднощів, що виникли в дитини;

- перспективний напрям, орієнтований на профілактику відхилень у навчанні та розвитку $[3$, c. 91$]$;

- реалізація програм індивідуальних та групових занять корекційно-розвивальної спрямованості.

Основними принципами психолого-педагогічного супроводу розвитку емпатії в молодших школярів виступають:

- принцип єдності діагностики та корекції корекційно-розвивальна робота 3 дітьми молодшого шкільного віку повинна здійснюватися на основі проведеної діагностики рівня емпатії; також протягом проведення корекційної роботи мають бути проведені діагностичні зрізи для визначення пї ефективності;

- діяльнісний принцип корекції визначає тактику проведення корекційної роботи через активізацію діяльності кожного учня, під час якої створюється необхідна основа для позитивних зрушень у розвитку емпатії в дитини;

- принцип урахування вікових, психологічних та індивідуальних особливостей - заняття повинні бути побудовані залежно від ступеня розвитку і відповідно до віку дітей;

- принцип комплексності методів;

- принцип поступовості - поетапне занурення дітей у психокоректувальний процес та поступовий вихід із цього процесу, а також збільшення глибини та сили впливів на дітей під час корекційної роботи;

- принцип урахування емоційної складності матеріалу - проводяться ігри, завдання, вправи, пропонований матеріал створює сприятливе емоційне тло, стимулює позитивні емоції. Кожне корекційне заняття завершується на позитивному емоційному тлі;

- принцип систематичності роботи 3 молодшими школярами.

Як зазначає А. Басова, психолого-педагогічний супровід розвитку емпатії як самостійної форми активності в дітей молодшого шкільного віку може проходити у три етапи. 
На першому етапі можуть застосовуватися вправи, спрямовані на розвиток емоційної емпатії, за темами: «Заспівай про свій настрій», «Вгадай, що я відчуваю», «Намалюй свій стан», «Придумай розповідь», «Вгадай, що відбувається» тощо.

На другому етапі - вправи, спрямовані на розвиток когнітивної емпатії по темі: колір, звук як засіб вираження розуміння емоційного стану іншої людини, включати такі завдання: «Зображення» та «Пантоміма» (у модифікації В. Петровського) тощо.

На третьому етапі можуть застосовуватися вправи, спрямовані на розвиток дієвої емпатії:

- читання літературних творів, у яких один літературний персонаж допомагає іншому;

- перегляд мультфільмів, вистав, основним змістом яких $\epsilon$ дієва емпатія героїв;

- переказ дітьми ситуації з їхнього власного досвіду, подібних за моральним змістом із сюжетами прочитаних літературних творів;

- бесіда про способи вираження дієвої емпатії $[4$, c. 58$]$.

Успішний психолого-педагогічний супровід розвитку емпатії й емпатійної поведінки в молодших школярів (співпереживання, співчуття до оточення) також можливий на базі розвитку творчої уяви під час поєднання видів дитячої діяльності (сприйняття художньої літератури, ігри, малювання), що опосередковують спілкування i взаємодію дорослого та дитини: співпереживання персонажам художнього твору, особливо казки, являє собою комплекс почуттів, до якого входять такі емоції, як: співчуття, осуд, гнів, подив. Ці соціально цінні емоції повинні ще закріпитися, актуалізуватися, привести до результату у відповідному контексті, який може і повинен створювати дорослий. Також можуть бути використані такі форми роботи, як: творчий ляльковий спектакль, гра - бесіда з персонажами, творчі та рольові ігри за сюжетом казки [3, с. 133].

Новою формою організації психолого-педагогічного супроводу є комплекс тематичних уроків 3 розвитку емпатії в молодших школярів. Тематичний урок як елемент виховного процесу виконує навчальну, виховну та розвивавальну функції, він дозволяє сформувати у школярів більш повні уявлення про гуманні якості особистості, їхне ставлення до них, а також сприяє формуванню ув дітей потреби в гуманній поведінці.

$\mathrm{У}$ роботі 3 молодшими школярами акцент робиться на бажання бути хорошим, що властиве дітям даного віку. У процесі психолого-педагогічного супроводу важливо орієнтуватися на бажання дати дитині моральну оцінку, отримати оцінку оточення.

Важливо починати ці заняття 3 дітьми 3 початкових класів. Тоді вони з раннього віку стимулюють пробудження в дитини гуманістичних засад особистості, у побудові взаємин з однолітками та дорослими, а також створюють умови для емоційного переживання набутих знань, їх усвідомлення і закріплення.

Структура етичних уроків розрахована на творчий процес пізнання дітьми емпатійної поведінки. Заняття проводяться в захоплюючій формі. Вони методично різноманітно побудовані, насичені грою, творчістю, діяльністю, вправами. Усе це поєднується 3 необхідним почуттям міри, без морального впливу на дітей. Психолог прагне до живого й опосередкованого включення дитини за допомогою різних методичних прийомів.

Дитина, яка послідовно і поступово опановує етичні знання та вміння їх застосовувати в повсякденному житті, вчиться бачити стан іншої людини, відгукуватися на цей стан. Так, за допомогою етичних уроків непомітно формується почуття емпатії, яке збагачує духовний світ людини.

Спеціальні методики на заняттях із дітьми дозволяють фіксувати процес розвитку рівня емпатії, моральних знань дітей, досвіду поведінки, ступінь просування або зміни в ціннісних орієнтаціях особистості.

У процес психолого-педагогічного супроводу розвитку емпатії природно включені методичні прийоми, які дозволяють психологу вивчати особливості дітей, простежувати динаміку їхнього розвитку, а також коректувати поведінку молодших школярів, їхні взаємини в колективі. Так, наприклад, психолог може запропонувати «надіслати листа до Миколая зі своїми потаємними бажаннями».

Тривалість занять у процесі психолого-педагогічного супроводу в початковій школі з урахуванням їхньої динамічності й емоційної насиченості не повинна бути більше 40 хвилин.

Під час психолого-педагогічного супроводу розвитку емпатії в молодших школярів психолог переконується, що в дитячому колективі поступово формується емпатійна поведінка, доброзичлива атмосфера взаємин, колективного спілкування, що сприятливо позначається в усіх сферах життєдіяльності дітей у школі. Зміст і атмосфера занять із дітьми впливають на сімейний клімат взаємин із дитиною, стимулюють прагнення до розуміння іншого, спонукають до відчуття емпатії в дитячій душі. 
Протягом усього психолого-педагогічного супроводу розвитку емпатії використовуються різні прийоми активізації морального та гуманістичного розвитку молодших школярів [5, с. 49], a came:

- прийоми, що стимулюють аналітично-оціночну діяльність школярів (афоризми, висловлювання видатних людей, прислів'я та приказки містять у собі глибоку мудрість, відкриття якої спонукає учнів до роздумів);

- аналіз моральних проблемних ситуацій. Найбільш інтенсивно оціночна діяльність розгортається на основі аналізу конкретних життєвих ситуацій, співвідношення дій та вчинків їхніх учасників з етичними нормами та принципами. Кращим матеріалом є ситуації, взяті із книг, фільмів, близькі досвіду учнів, а також життєві ситуації, ідентичні тим, які виникають у практичній діяльності, міжособистісній взаємодії самих дітей. Проблемна ситуація може стати поштовхом до початку бесіди, дискусії, що викликає емпатійну поведінку у школярів;

- методика «Дилема» призначена для оцінки рівня розвитку моральної свідомості та має чотири основні характеристики. Вона повинна:

1) стосуватися реального життя учнів;

2) бути (за можливості) простою для розуміння;

3) бути незакінченою;

4) включати два або більше питань, наповнених моральним змістом;

- рефлексія у формі гри. Існує ціла низка ігор, що дозволяють створити ситуацію розвитку емпатії, певного емоційного досвіду та його усвідомлення, осмислення за допомогою наступної рефлексії своїх почуттів та переживань. Рефлексія в даному разі є найважливішим та необхідним етапом, бо саме завдяки їй у дітей з' являються власні висновки та відкриття;

- за допомогою прийомів моральної активізації необхідно органічно ввести їх у структуру і логіку занять, чітко розуміти, які завдання вирішує кожен i3 них, поєднувати різноманітні прийоми. I найголовніше, моделювати і будувати за аналогією вправи і завдання на основі різного етичного матеріалу. Найважливіша роль належить психологу в узагальненні та систематизації тих думок і почуттів, які виникають у школярів у процесі активної ціннісно орієнтовної діяльності, а також в іiі продовженні й організації відповідних емоційних відгуків у колективі і поза ним після занять.

Одним з основних завдань психолого-педагогічного супроводу розвитку емпатії в молодших школярів є розвиток здатності дітей до диференціації емоційних станів через усвідомлення власних переживань. Із цією метою використовуються елементи психогімнастики за методикою Г. Бардієр, І. Ромазан, Т. Чередникової. Психогімнастика - це курс спеціальних занять (етюди, ігри, вправи), спрямованих на розвиток емпатії. Діти вивчають різні емоції та вчаться керувати ними, опановують «абетку» вираження емоцій. Психогімнастика допомагає дітям долати бар'єри у спілкуванні, краще зрозуміти себе й інших, знімати психічне напруження, дає можливість самовираження.

Дуже важлива словесна мова почуттів, яка позначає явища емоційного життя. Назва емоцій у психогімнастиці веде до емоційного усвідомлення дитиною себе. Дитина, що говорить хорошою та збагаченою мовою, краще мислить, у неї з'являється більше відтінків для словесного позначення почуттів, вона тонше розуміє себе, свої переживання, емоції в неї стають більш диференційованими. Психологи вважають, що резерви підвищення дієвості моральних уявлень дитини лежать в емоційній насиченості змісту оціночних суджень дорослих, у використанні ними оцінок особистісних властивостей, оцінок-станів, оцінок-передбачень, інших форм емоційних відносин, що відповідають рівню морального розвитку школяра [1, с. 3].

У процесі проведення занять із психогімнастики, їх підготовки та проведення необхідно враховувати такі моменти:

1. Кожна вправа включає в діяльність фантазію (думки, образи), почуття (емоції), рухи дитини так, щоб через механізм їхньої функціональної єдності дитина вчилася довільно впливати на кожен з елементів цієї тріади.

2. Усі зайняті будуються на сюжетно-рольовому змісті.

3. Усі предмети і події повинні бути уявними. Це полегшує тренування внутрішньої уваги дітей.

4. У структуру занять мають входити: розминка, гімнастика, емоції, спілкування, поведінка та завершення.

Висновки. Отже, психолого-педагогічний супровід розвитку емпатії в молодших школярів $\epsilon$ основою у формуванні особистості дитини. Особливу увагу, на нашу думку, батькам і психологам варто звертати на те, як дитина розуміє і реагує на стан іншої людини (емоційний компонент), тому що важливим $є$ не тільки співчуття негативним емоціям, але і радість щодо позитивних емоцій іншої людини. 


\section{Список літератури:}

1. Абрамова Г. Возрастная психология. Москва : Аст-Пресс-Екатеринбург, 2000. С. 184-510.

2. Абульханова-Славская К. Деятельность и психология личности. Москва : Просвещение, 2010. 335 с.

3. Василюк Ф. Психология переживания. Москва : Академия, 2011. 200с.

4. Выготский Л. Избранные труды. Москва : Просвещение, 2010. 317 с.

5. Гаврилова Т. Понятие эмпатии в зарубежной психологии. Вопросы психологии. 2012. № 2. С. 147-156.

6. Основи батьківської компетентності / за заг. ред. І. Звєрєвої. Київ : Наук. світ, 2006. 156 с.

\section{Fomina I.S., Los O.M. PSYCHOLOGICAL AND PEDAGOGICAL SUPPORT OF EMPATHY DEVELOPMENT IN JUNIOR SCHOOLCHILDREN}

The article deals with support as the basis of professional activity of school psychologists, which is focused on creating conditions for the development of empathy of each child in situations of school interaction.

To provide psychological and pedagogical support for the development of empathy in junior high school students, psychologists suggest using a variety of activities: games, productive activities, subject activities, observation, communication. Special techniques in classes with children allow you to record the process of development of the level of empathy, moral knowledge of children, experience of behavior, and the degree of advancement or change in the value orientations of the individual.

One of the main tasks of psychological and pedagogical support for the development of empathy in junior high school students is the development of children's ability to differentiate emotional states through awareness of their own experiences. For this purpose, elements of psychogymnastics are used according to the method of G. Bardier, I. Romazan, T. Cherednikova. Successful psychological and pedagogical support for the development of empathy and empathic behavior in junior high school students is possible on the basis of the development of creative imagination in a combination of children's activities.

The thematic lesson, as an element of the educational process, performs educational, upbringing and developmental functions, it allows students to form more complete ideas about the humane qualities of the individual, his attitude to them, and also contributes to the formation of children's need for humane behavior.

The process of psychological and pedagogical support for the development of empathy naturally includes methodological techniques that allow the psychologist to study the characteristics of children, to track the dynamics of their development, as well as to correct the behavior of younger students, their relationships in the team.

Key words: empathy, personality development, junior schoolchildren. 